\title{
Role of globalization and sustainable engineering practice in the future civil engineering education
}

\author{
M. K. Jha ${ }^{1} \&$ D. R. Lynch ${ }^{2}$ \\ ${ }^{I}$ Department of Civil Engineering, Morgan State University, USA \\ ${ }^{2}$ Department of Engineering Sciences, Dartmouth College, USA
}

\begin{abstract}
We are living in a world that is increasingly interconnected. Countries and their social, constructed, and natural environments demonstrate emerging interdependencies that must be considered in planning and selecting engineering projects. Immediate access to information is everywhere and, in many respects, geographic proximity is becoming less important to the success of a project. Engineers will need to deal with ever-increasing globalization and find ways to prosper within an integrated international environment, and meeting challenges which cross cultural, language, legal, and political boundaries, while respecting critical cultural constraints and differences.

Sustainable engineering practice should meet human needs for natural resources, industrial products, energy, food, transportation, shelter, and effective waste management while conserving and protecting environmental quality and the natural resource base essential for future development. This paper addresses the issue of sustainable engineering practice in the context of globalization. It is based on the efforts made by the members of the American Society of Civil Engineers (ASCE)-Body of Knowledge ( $2^{\text {nd }}$ edition) committee in ensuring that a civil engineer of 2020 and beyond will have the requisite understanding of globalization and sustainable engineering practices to enter into the practice of the profession. Specifically, the paper addresses the critical aspects of a sustainable civil society sought by the global profession of civil engineering; and the approach to realization within ASCE.

Keywords: sustainable development, civil engineering, body of knowledge, globalization.
\end{abstract}




\section{Introduction}

In recent years there has been considerable awareness and greater acknowledgement to consider sustainability and globalization in future civil engineering curriculum. Tomorrow's civil engineers will be faced with growing need for designing and constructing sustainable civil infrastructure, handling global issues, and working in a global environment. This paper addresses the efforts made by American Society of Civil Engineers' Body of Knowledge, $2^{\text {nd }}$ Edition (ASCE-BOK2) committee towards considering sustainability and globalization as required skills that a civil engineer of year 2020 and beyond should possess before entering into the civil engineering profession.

\section{ASCE-Body of Knowledge}

\subsection{History of ASCE-BOK}

The American Society of Civil Engineers (ASCE) Policy Statement 465, unanimously adopted by the Board of Direction in 2001, states that the Society "...supports the concept of the master's degree or equivalent as a prerequisite for licensure and the practice of civil engineering at the professional level [1]." The ASCE created the Task Committee on Academic Prerequisites for Professional Practice $\left(\mathrm{TCAP}^{3}\right)$ to "develop, organize and execute a detailed plan for full realization of Policy Statement 465." (In November 2003, in recognition of the long-term nature of implementing Policy Statement 465, TCAP $^{3}$ was changed to the Committee on Academic Prerequisites for Professional Practice [ $\mathrm{CAP}^{3}$ ], a permanent Board-level committee.) TCAP $^{3}$ developed an implementation master plan for which the Body of Knowledge (BOK) was the foundation. TCAP ${ }^{3}$ subsequently formed the Body of Knowledge Committee and its charge included defining the BOK, addressing the role of experience and describing the roles of faculty, practitioners, and students.

The BOK Committee conducted its deliberations and presented its recommendations in January 2004 [1]. The recommendations included three themes: (1) what should be taught to and learned by future civil engineering students; (2) how should it be taught and learned; and (3) who should teach and learn it. The Committee's primary focus was the what.

The what recommendations were cast in terms of 15 outcomes that, compared to today's bachelor's programs, included significant increases in technical depth and professional practice breadth. Each outcome was further described with a civil engineering commentary. The outcomes included recognition, understanding or ability competency levels in broad and deep areas essential to the future practice of civil engineering at the professional level.

ASCE Policy Statement 465's and BOK's stand of a masters degree (or equivalent) to be the minimum educational level before entering into the practice of civil engineering needed further discussion in order for it to be widely embraced by the stakeholders consisting of academia and industry. As a result, 
ASCE formed the second Body of Knowledge (BOK2) committee in October 2005 to rethink and redesign the outcomes and minimum educational level before entering into the professional practice of civil engineering.

\subsection{The ASCE commitment to Sustainable Development}

Concurrently with the development of BOK1, ASCE continued to commit the profession to both the sustainability and international development imperatives.

The ASCE definition was adopted in November 1996:

Sustainable Development is the challenge of meeting human needs for natural resources, industrial products, energy, food, transportation, shelter, and effective waste management while conserving and protecting environmental quality and the natural resource base essential for future development.

The ethical obligation of the profession was recognized then (and remains so) in the ASCE Code of Ethics:

Engineers shall hold paramount the safety, health and welfare of the public and shall strive to comply with the principles of sustainable development in the performance of their professional duties (A comparable ethics statement was adopted in 2006 by NSPE).

In June 2002, the "Dialog on the Engineers' Role in Sustainable Development Johannesburg and Beyond" [3] committed its signatories (AAES, AIChE, ASME, NAE, NSPE) to the declaration:

Creating a sustainable world that provides a safe, secure, healthy life for all peoples is a priority for the US engineering community. ... Engineers must deliver solutions that are technically viable, commercially feasible and, environmentally and socially sustainable.

Reinforcing this and related NAE [4,5] themes, ASCE convened a summit of leaders of the profession in 2006. The vision expressed therein [6]:

Entrusted by society to create a sustainable world and enhance the global quality of life, civil engineers serve competently, collaboratively, and ethically as master:

- $\quad$ planners, designers, constructors, and operators of society's economic and social engine, the built environment;

- $\quad$ stewards of the natural environment and its resources;

- innovators and integrators of ideas and technology across the public, private, and academic sectors;

- managers of risk and uncertainty caused by natural events, accidents, and other threats; and

- leaders in discussions and decisions shaping public environmental and infrastructure policy.

This vision is broadly assertive of aspirations to sustainable engineering, stewardship of the natural resources and the environment, and the fostering and integration of innovation in service of these ends - all in the basic overriding context of service to people through civilian engineering.

These commitments are top-down. Adjusting the Body of Knowledge to reflect the twin themes of Sustainability and Globalism, is implied. 


\subsection{ASCE BOK2}

The BOK2 consists of fourteen regular members and numerous corresponding members drawn from industry and academia. Since its formation in October 2005 a face-to-face meeting every two-three months (or at intervals found necessary) and a weekly or biweekly (as desired) conference call have been held to discuss the required outcomes to be accomplished though a combination of education and experience before entering into the professional practice of civil engineering.

Outcomes are the principal means being used to define what should be taught to and learned by tomorrow's civil engineers [2]. Outcome clarifications can be achieved through the use of organizing frameworks or taxonomies that systematically differentiate outcome characteristics and promote common understandings for all potential users of the BOK. The BOK2 committee, of which the authors are regular members, has included sustainability and globalization as two new, freestanding outcomes. A list of tentative outcomes adopted by the BOK2 committee as of December 2006 is shown in Figure 1.

\section{Sustainability}

The $21^{\text {st }}$ Century Civil Engineer must demonstrate an ability to analyze the sustainability of engineered systems, and of the natural resource base on which they depend; and to design accordingly. American Society of Civil Engineers (ASCE) embraced sustainability as an ethical obligation in 1996, and Policy Statement 418 points to the leadership role that civil engineers must play in sustainable development. The 2006 ASCE Summit called for renewed professional commitment to stewardship of natural resources and the environment. Knowledge of the principles of sustainability, and their expression in engineering practice, is required of all civil engineers.

There are social, economic, and physical aspects of sustainability. The latter includes both natural resources and the environment. Technology affects all three and a broad, integrative understanding is necessary in support of the public interest. Beyond that, special competence is required in the scientific understanding of natural resources and the environment, which are the foundation of all human activity; and the integration of this knowledge into practical designs that support and sustain human development. Vest referred to this as the primary systems problem facing the $21^{\text {st }}$ century engineer.

The actual life of an engineered work may extend well beyond the design life; and the actual outcomes may be more comprehensive than initial design intentions. The burden of the engineer is to address sustainability in this longer and wider framework.

Individual projects make separate claims on the collective future; ultimately they cannot be considered in isolation. A commitment to sustainable engineering implies a commitment, across the profession, to the resolution of the cumulative effects of individual projects. Ignoring cumulative effects can lead to overall failure. This concern must be expressed by the profession generally, and affect its interaction with civil society. 


\begin{tabular}{|l|l|}
\hline \multicolumn{2}{|c|}{ Foundation } \\
\hline 1 & Mathematics \\
\hline 2 & Physics \\
\hline 3 & Chemistry \\
\hline 4 & Breadth in basic science \\
\hline 5 & Humanities \\
\hline 6 & Social sciences \\
\hline
\end{tabular}

\begin{tabular}{|c|c|c|c|c|c|}
\hline $\begin{array}{c}\mathbf{1} \\
\text { Knowledge }\end{array}$ & $\begin{array}{c}\mathbf{2} \\
\text { Comprehension }\end{array}$ & $\begin{array}{c}\mathbf{3} \\
\text { Application }\end{array}$ & $\begin{array}{c}\mathbf{4} \\
\text { Analysis }\end{array}$ & $\begin{array}{c}\mathbf{5} \\
\text { Synthesis }\end{array}$ & $\begin{array}{c}\mathbf{6} \\
\text { Evaluation }\end{array}$ \\
\hline B & B & B & & \\
\hline B & B & B & \\
\hline B & B & B \\
\hline B & B & B \\
\hline B & B & B \\
\hline B & B & B \\
\hline
\end{tabular}

\begin{tabular}{|c|l|}
\hline \multicolumn{2}{|c|}{ Technical } \\
\hline 5 & Mechanics of Physical Systems \\
\hline 6 & Behavior of Materials \\
\hline 7 & Breadth in civil engineering areas \\
\hline 8 & Engineering tools \\
\hline 9 & Engineering problem solving \\
\hline 10 & Design \\
\hline 11 & Experiments \\
\hline 12 & Contemporary \& emerging issues \\
\hline 13 & Risk/uncertainty \\
\hline 14 & Sustainability \\
\hline 15 & Project management \\
\hline D & Construction management \\
\hline D & Asset management \\
\hline 16 & Technical specialization \\
\hline
\end{tabular}

\begin{tabular}{|c|c|c|c|c|c|}
\hline $\begin{array}{c}1 \\
\text { Knowledge }\end{array}$ & $\begin{array}{c}\mathbf{2} \\
\text { Comprehension }\end{array}$ & $\begin{array}{c}\mathbf{3} \\
\text { Application }\end{array}$ & $\begin{array}{c}\mathbf{4} \\
\text { Analysis }\end{array}$ & $\begin{array}{c}\mathbf{5} \\
\text { Synthesis }\end{array}$ & $\begin{array}{c}6 \\
\text { Evaluation }\end{array}$ \\
\hline B & B & B & B & & \\
\hline B & B & B & & & \\
\hline B & B & B & B & & \\
\hline B & B & B & $\mathrm{M} / 30$ & & \\
\hline B & B & B & $\mathrm{M} / 30$ & & \\
\hline B & B & B & B & $B$ & $E$ \\
\hline B & B & B & B & $\mathrm{M} / 30$ & \\
\hline B & B & B & $E$ & & \\
\hline B & B & B & $E$ & & \\
\hline B & B & B & $E$ & & \\
\hline B & B & B & E & & \\
\hline B & & & & & \\
\hline B & & & & & \\
\hline B & $\mathrm{M} / 30$ & $\mathrm{M} / 30$ & $\mathrm{M} / 30$ & $\mathrm{M} / 30$ & $E$ \\
\hline
\end{tabular}

\begin{tabular}{|l|l|}
\hline \multicolumn{2}{|c|}{ Professional } \\
\hline 17 & Communication \\
\hline 18 & History and heritage \\
\hline 19 & Globalization \\
\hline 20 & Prof. \& ethical responsibility \\
\hline 21 & Public policy \\
\hline 22 & Business \& public administration \\
\hline 23 & Teamwork \\
\hline 24 & Leadership \\
\hline 25 & Life-long learning \\
\hline 26 & Attitudes \\
\hline
\end{tabular}

\begin{tabular}{|c|c|c|c|c|c|}
\hline $\begin{array}{c}1 \\
\text { Knowledge }\end{array}$ & $\begin{array}{c}\mathbf{2} \\
\text { Comprehension }\end{array}$ & $\begin{array}{c}3 \\
\text { Application }\end{array}$ & $\begin{array}{c}4 \\
\text { Analysis }\end{array}$ & $\begin{array}{c}\mathbf{5} \\
\text { Synthesis }\end{array}$ & $\begin{array}{c}6 \\
\text { Evaluation }\end{array}$ \\
\hline B & B & B & B & E & \\
\hline B & B & & & & \\
\hline B & B & B & B & & \\
\hline B & B & B & B & $\mathrm{E}$ & $E$ \\
\hline B & B & $\mathrm{E}$ & & & \\
\hline B & B & $\mathrm{E}$ & & & \\
\hline B & B & B & $\mathrm{E}$ & & \\
\hline B & B & B & $\mathrm{E}$ & & \\
\hline B & B & B & $\mathrm{E}$ & $\mathrm{E}$ & \\
\hline B & B & $\mathrm{E}$ & & & \\
\hline
\end{tabular}

Key:

\begin{tabular}{|c|c|}
\hline B & Portion of Body of Knowledge fulfilled through the Bachelor's degree. \\
\hline $\mathrm{M} / 30$ & Portion of Body of Knowledge fulfilled through the Master's degree or the \\
\hline & equivalent \\
\hline $\mathrm{E}$ & ortion of Body of Knowledge fulfilled through pre-licensure experience. \\
\hline
\end{tabular}

Figure 1: BOK2 Outcomes (vertical), achievement level (horizontal), and professional development stage (darker color). 
Relative to the requirements for every civil engineer: the current $\mathrm{BOK} 2$ stipulation is:

Upon graduation from a baccalaureate program, an individual must be able to apply the principles of sustainability to the design of traditional and emergent systems (Level 3). Implied is mastery of a) the scientific understanding of natural resources and the environment, and b) the ethical obligation to relate these sustainably to the public interest. This mastery must rest on a wide educational base [7], supporting 2way communication with the service population about the desirability of sustainability and its scientific and technical possibilities.

Upon completion of pre-licensure experience and before entry into the practice of civil engineering at the professional level, an individual must be able to analyze systems of engineered works, whether traditional or emergent, for sustainable performance (Level 4). Analysis assumes a scientific, systems-level integration and evaluation of social, economic, and physical factors - the three aspects of sustainability. Achievement at this level requires the " $\mathrm{B}$ " achievement described above to be advanced in practice to the analysis level, through structured experience and in synergy with other real works, built or planned. Successful progression of cognitive development in this experiential phase must be demonstrable.

These requirements are the minima. Individual achievements will on average exceed these and performance of the profession in the aggregate, and beyond Licensure, are described in the attached Rubric (Figure 2). They imply further competence and achievement.

\section{Globalization}

We are living in a world that is increasingly interconnected. Countries and their social, constructed, and natural environments demonstrate emerging interdependencies that must be considered in planning and selecting projects. Immediate access to information is everywhere and, in many respects, geographic proximity is becoming less important to the success of a project [8]. Engineers will need to deal with ever-increasing globalization and find ways to prosper within an integrated international environment, and meeting challenges which cross cultural, language, legal, and political boundaries, while respecting critical cultural constraints and differences $[9,10]$. The $21^{\text {st }}$ century civil engineer must address three distinct issues, the globalization process, global issues, and global professionalism. Some examples include:

\section{Globalization Process:}

- globalization's effect on infrastructure revitalization in the US;

- the dependency of economic wealth on the variety, reliability and service of physical infrastructure systems;

- $\quad$ cost and Governmental issues 
Global Issues:

- the international scale of extreme and long-term environmental events, such as disasters, global climate change, and their impacts on the natural, built, and social environments;

- meeting a world health standard;

- developing acceptable international standards for both large and developing countries.

Global Professionalism:

- individuals, businesses, and the profession becoming effective in multicultural practice;

- the challenge of practicing ethically in a global environment;

- barriers to professional licensure, contractor licenses/permits, and foreign corporations.

The current BOK2 stipulation for this outcome is:

Upon graduation from a baccalaureate program, an individual must be able to analyze engineering works and services in order to function at a basic level in a global context. (Level 4).

Individuals are expected to be able to analyze the impact of globalization process, global issues, and global professionalism through industry interaction, professional society interaction, co-ops, international service opportunities, and related coursework.

\section{The Foundation}

Included in the BOK2 at this point are specific outcomes in the Humanities and the Social Sciences. These were historically included as academic requirements for the BS, but were generally not utilized in support of anything beyond "general education". BOK2 is explicitly articulating these as independent foundational outcomes, in parallel with Mathematics and the Sciences. Elsewhere [11] we elaborate on this. Here we wish only to point out that sustainability makes claims on Civil Engineering in three ways relative to the human habitat: (1) Natural Resources that sustain human activity, and the Environment which sustains all life; (2) the constructed environment; and (3) the social environment. Inability to understand and deal creatively with the latter, leads to failure. Hence, a "Sustainability" outcome makes claims on the Humanities and the Social Science bases. Similar points are to be made relative to Globalism. Engineers who purport to function in a Global economy, on Global teams, and indeed to serve as leaders of such teams: will have to apply universal principles to very locally-defined and -constrained problems. Hence a Globalization outcome implies claims on the educational base. The two special entries in the foundational category are not simply unconstrained general education requirements. They are required to support and contribute to the two primary outcomes discussed here (and others as well). This is implied in the professional commitments described at the start of this paper. 


\begin{tabular}{|c|c|}
\hline \multirow{2}{*}{$\begin{array}{l}\text { Level I } \\
\text { Knowledge } \\
\text { (B) }\end{array}$} & $\begin{array}{l}\text { Define key aspects of sustainability relative to engineering phenomena, society } \\
\text { at large and its dependence on natural resources, and the ethical obligation of } \\
\text { the professional engineer. }\end{array}$ \\
\hline & $\begin{array}{l}\text { Rationale: Proactive integration of diverse considerations is implied at the point } \\
\text { where an engineering solution is proposed and evaluated. Implied is an ability } \\
\text { to conceive of the full lifecycle of an engineering project, and a comprehensive } \\
\text { set of outcomes, including effects on the environment, the natural resource base, } \\
\text { the conditions at project termination, and the appropriateness of the project itself } \\
\text { and how it serves Public Interest. }\end{array}$ \\
\hline \multirow{2}{*}{$\begin{array}{l}\text { Level II } \\
\text { Comprehensic } \\
\text { (B) }\end{array}$} & $\begin{array}{l}\text { Explain key properties of sustainability, and their scientific bases, as they } \\
\text { pertain to engineered works and services. }\end{array}$ \\
\hline & $\begin{array}{l}\text { Rationale: This is the natural extension of Level I. A blend of theory and } \\
\text { experiment is likely in applying ideas to engineered systems. A scientific } \\
\text { explanation is necessary, especially relative to Natural Resources and to the } \\
\text { natural and built environment, where established scientific descriptions are } \\
\text { available. }\end{array}$ \\
\hline \multirow{2}{*}{$\begin{array}{l}\text { Level III } \\
\text { Application } \\
\text { (B) }\end{array}$} & $\begin{array}{l}\text { Apply the principles of sustainability to the design of traditional and emergent } \\
\text { engineering systems. }\end{array}$ \\
\hline & $\begin{array}{l}\text { Rationale: This is the natural extension of Level II. Graduate must be capable } \\
\text { of applying ideas to real engineering works; and of utilizing general information } \\
\text { available within the profession. }\end{array}$ \\
\hline \multirow{2}{*}{$\begin{array}{l}\text { Level IV } \\
\text { Analysis } \\
\text { (Experience } \\
\text { Pre-Licensure }\end{array}$} & $\begin{array}{l}\text { Analyze systems of engineered works, whether traditional or emergent, for } \\
\text { sustainable performance. }\end{array}$ \\
\hline & $\begin{array}{l}\text { Rationale: This is a systems-level integration of cumulative and synergistic } \\
\text { effects of works with respect the sustainability of the composite outcome. } \\
\text { Implied is the ability to propose and compare alternatives in an analytic } \\
\text { framework. }\end{array}$ \\
\hline \multirow{2}{*}{$\begin{array}{l}\text { Level V } \\
\text { Synthesis } \\
\text { (Experience } \\
\text { Post-Licensure) }\end{array}$} & $\begin{array}{l}\text { Design a complex system, process, or project to perform sustainably; Develop } \\
\text { new, more sustainable technology; Create new knowledge or forms of analysis } \\
\text { in areas where scientific knowledge limits sustainable design. }\end{array}$ \\
\hline & $\begin{array}{l}\text { Rationale: This is either professional-strength design, or research. The latter } \\
\text { can have varying amounts of scientific overlap. }\end{array}$ \\
\hline \multirow{2}{*}{$\begin{array}{l}\text { Level VI } \\
\text { Evaluation } \\
\text { (Experience } \\
\text { Post-Licensure) }\end{array}$} & Evaluate the sustainability of complex systems, whether proposed or existing. \\
\hline & $\begin{array}{l}\text { Rationale: This is referring to the ability to inspire and evaluate the work of } \\
\text { teams engaged synergistically. Included is the ability to quantify the value of } \\
\text { research in sustainable engineering. }\end{array}$ \\
\hline
\end{tabular}

Figure 2: $\quad$ RUBRIC for Sustainability: a longitudinal profile of an individual professional's development.

\section{$6 \quad$ Timing}

The BOK portrays minimum outcomes for all BS graduates, and all pre-licensure interns. With immediate implementation, this puts us 4-8 years from realization of these competencies, and beyond for the engineered works and services themselves. Add to that the time required to accept these recommendations, 
adjust programs, etc., and we are at least a decade away from production. In addition, the average working life of current engineers might be 1-3 decades, and unaddressed, that will further delay full realization. Alone, this is a frontloading strategy facing these timing delays. Current imperatives require faster action; hence, a broad educational program in these areas is needed that addresses working engineers, in parallel with the preparation of new engineers. This dual strategy is more fully developed in Lynch and Russell [12].

\section{Discussion}

This paper addressed the ongoing initiatives of ASCE's BOK2 committee to include sustainability and globalization in the future civil engineering curriculum. The committee is expected to wrap-up its efforts by the engineers' week in February 2008 at which time its deliberations will be made public. The findings of the committee will be compiled in a book similar to that released by the first BOK committee [1]. The final deliberations will consist of specific outcomes and rubrics and required education and experience to achieve them. A sample rubric for Sustainability showing a longitudinal profile of an individual professional's development is shown in Figure 2.

The work of the committee is regarded as of very high quality and frequently cited by engineering professionals, educators, and other stakeholders in discussions, meetings, and conferences pertaining to civil engineering education. It is anticipated that the deliberations of the committee will be implemented by educators, industries, and politicians to improve the quality of civil engineering education in the United States and around the globe.

\section{Acknowledgements}

The authors acknowledge the ASCE-BOK2 committee for its ongoing efforts to promote and encourage the inclusion of sustainability and globalization. Special thanks to J. Russell, T. Lenox and R. Anderson for their leadership and vision towards the ASCE-BOK2 initiatives.

\section{References}

[1] ASCE Body of Knowledge Committee, Civil Engineering Body of Knowledge for the 21st Century: Preparing the Civil Engineering for the Future. Reston, VA: ASCE, 2004.

[2] Walsh, S.G., Body of Knowledge for Civil Engineers: Essential for Success in the International Arena, proceedings of the 35th International IGIP Symposium in cooperation with IEEE / ASEE / SEFI, 2006-09-18, Tallinn, Estonia, 2006.

[3] NAE, Dialog on the Engineers' Role in Sustainable Development Johannesburg and Beyond, National Academy of Engineering, 2002.

[4] The Engineer of 2020: Visions of Engineering in the New Century. National Academy of Engineering, 2004. 
[5] Educating The Engineer of 2020: Adapting Engineering Education to the New Century. National Academy of Engineering, 2005.

[6] The Vision For Civil Engineering in 2025. Proc. Summit on the Future of Civil Engineering, June $21-22,2006$. Task Committee on the Future of the Civil Engineering Profession, ASCE, S.G. Walesh, ed. Draft January 5, 2007.

[7] Frank T. Rhodes, "Sustainability: the Ultimate Liberal Art". The Chronicle of Higher Education, Oct. 20, 2006.

[8] Arciszewski, T., "Civil Engineering Crisis," ASCE Journal of Leadership and Management in Engineering, pp. 26-30, January, 2006.

[9] Civil Engineering Body of Knowledge for the 21st Century: Preparing the Civil Engineer for the Future. ASCE Body of Knowledge Committee, 2004.

[10] Rising Above the Gathering Storm: Energizing and Employing America for a Brighter Economic Future. National Academies Press, 2006.

[11] "The Role of Humanities and Social Sciences in the Civil Engineering Body of Knowledge", J. Evans, D. Lynch, D. Lange. Proc. American Society of Engineering Education, Annual Conference and Exhibition, Honolulu, June 2007.

[12] "Experiential Learning in Engineering Practice", D.R. Lynch and J.S. Russell. J. Professional Issues in Civil Engineering, in review 2007. 